\title{
Influence of environmental factors on the working rhythm in a clothing industry \\ DOI: 10.35530/IT.072.01.1563
}

\author{
AMIRA LAKHAL \\ NEJIB SEJRI \\ FADHEL JAAFAR
}

\author{
YASSINE CHAABOUNI \\ MORCHED CHEIKHROUHOU
}

\section{ABSTRACT - REZUMAT \\ Influence of environmental factors on the working rhythm in a clothing industry}

The working environment is an essential element for the health and safety of the work and for the improvement of productivity. So, the conditions in the clothing industry are the most productive of occupational diseases such as MSDs, deafness and eye diseases. In this paper, we made an analysis of the environment in a clothing industry for each workplace using the NF EN ISO 2612 standard to analyze the level of sound exposure, the standard NBN EN 12464-1 is used to analyze the level of light for a sewing workplace. The noise level varies between $73 \mathrm{dBA}$ and $90.5 \mathrm{dBA}$ depending on the type of workplace. The lighting at the working zone varies between $240 \mathrm{Ix}$ and 1100 Ix. The average temperature level varies between $28^{\circ} \mathrm{C}$ for the ironing stations and $26^{\circ} \mathrm{C}$ for the other stations and the average humidity level is $50 \%$. The percentage of quality varies between 0 and $5 \%$. An objective method was developed to determine the general pace of a sewing post which contains the atmosphere factors with regard to the noise level, the lighting level, the level of quality, the temperature level and the humidity. According to these parameters, the average pace of the studied group decreased from 98 to 78.

Keywords: lighting level, noise level, temperature, humidity, quality, workplace

\section{Influența factorilor de mediu asupra ritmului de lucru în industria de îmbrăcăminte}

Mediul de lucru este un element esențial pentru sănătatea și siguranța muncii și pentru îmbunătățirea productivității. Astfel, condițiile de lucru din industria de îmbrăcăminte sunt cele care produc boli profesionale, cum ar fi MSD, surditatea și bolile oculare. În această lucrare, s-a realizat o analiză a mediului din industria de îmbrăcăminte pentru fiecare loc de muncă, folosind standardul NF EN ISO 2612 pentru a evalua nivelul de expunere la zgomot și standardul NBN EN 12464-1 pentru a evalua nivelul de iluminare aferent locului de muncă de la mașina de cusut. Nivelul de zgomot variază între 73 dBA și 90,5 dBA în funcție de tipul locului de muncă. Iluminatul din zona de lucru variază între 240 Ix și 1100 Ix. Nivelul mediu de temperatură variază între $28^{\circ} \mathrm{C}$ pentru stațiile de călcat și $26^{\circ} \mathrm{C}$ pentru celelalte stații, iar nivelul mediu de umiditate este de $50 \%$. Procentul de calitate variază între 0 și $5 \%$. O metodă obiectivă a fost dezvoltată pentru a determina ritmul general al unui post de coasere, care conține factorii atmosferici în ceea ce privește nivelul de zgomot, nivelul de iluminare, nivelul de calitate, nivelul de temperatură și umiditatea. Conform acestor parametri, ritmul mediu al grupului studiat a scăzut de la 98 la 78.

Cuvinte-cheie: nivelul de iluminare, nivelul de zgomot, temperatura, umiditatea, calitatea, locul de muncă

\section{INTRODUCTION}

The sewing operations are very varied, which induces different procedures with high and repetitive rhythms. The lasts decrease the motivation of the workers, which diminish production on the one hand and influence their health and cause several types of occupational diseases, which the most recognized are musculoskeletal disorders TMS [1-3]. The work environment still influences the health of the worker and may be a source of other types of occupational diseases such as hearing diseases due to prolonged sound exposure to a high noise level. According to the U.S. Occupational Noise Exposure Regulation, $90 \mathrm{dBA}$ is the maximum dose for a period for 8 hours [4]. In Turkey, the maximum dose should be less than 75 dBA for a period for 7.5 hours [5]. A survey was conducted by the European Agency for Safety and
Health at Work indicates that $67 \%$ of French workers are disturbed by noise at their place of work. According to the Sumer study (2010, France), longterm exposures and more than 20 hours per week with high levels (more than $85 \mathrm{~dB}$ ) concern $16.8 \%$ of employees in industries. Deafness is the second most common occupational disease and 750 cases are reported each year [5]. As well as the lighting not in accordance with the requirement may be the cause of dazzling eyes, headaches and work will be boring and not stimulating which decreases productivity [6]. The objective of this study is to carry out an analysis of the working environment in a clothing industry by using the NF EN ISO 9612 [7] standard to analyze the level of sound exposure, the standard NBN EN 12464-1 [8] is used to analyze the level of light for a sewing post. According to this analysis, an 
objective method must be developed to determine the general appearance of a sewing workplace which contains the environmental factors with regard to the noise level, the lighting level, the temperature level and the humidity.

\section{METHOD}

The analysis of the environment in this study was made in an assembly line of articles prepared in the manufacture of jackets men. The chain is consisted of 50 workers at the similar conditions. The simple sewing machine, buttonhole, button pressing, welt pocket, ironing, simple table for the control and cleaning are used in our study. According to the standard "NFEN ISO 9612" [7], the study was begun with an analysis of the noise exposition level. The method consists of measuring the level of noise by the following approach:

- An analysis of the work while observing the workstation and measuring the cycle duration by the method of measuring stitching time [9].

- A selection of the measurement strategy: The chosen strategy is based on a full day measurement.

- Measure the noise level for each activity by breaking down the task into two levels; when the machine is running and the machine is stopped when the worker is performing manual tasks. The measurement was realized by a portable digital sound level meter HD600. The noise level was measured in the head position of the employees, for each post 5 measurements were taken at a period of 2030 seconds [10].

- Treatment of errors and calculation of daily exposure level according to the following equation:

$$
L e x, 8 H=L P, A, T_{e}+10 \lg \left(T_{e} / T_{0}\right)
$$

where $L P, A$, eq $T_{e}$ is the continuous acoustic level of pressure balanced equivalent, $A$ calculated by the average, $T_{e}$ is the effective duration of the working day, $T_{0}$ - the standard duration $\left(T_{0}=8\right.$ hours). A calculator was used to estimate the sound and total exposure for each workplace [11]. The second analysis was made according to the standard NBN EN 12464-1 [8] in order to measure the lighting level for each workplace. The approach taken for this analysis is as follows:

- Measurement of lighting level in the immediate surrounding zone which was defined by a band of at least $0.5 \mathrm{~m}$ around the working zone in the field of vision.

- Measurement of lighting level of the bottom zone which is defined by a band of at least $3 \mathrm{~m}$ width adjacent to the immediate surrounding zone. The measurement was made by a digital luxmeter TES 1332. Illumination was measured at the work site at a height of 0.85 meters above ground level [12].

- Determination of the ratio of illumination between the work area, the surrounding area and the bottom area.

- Determine the uniformity of the lighting according to the following equation:

$$
U_{0}=\frac{L_{\min }}{L_{\max }}
$$

The analysis of the atmosphere was ended with the measure of the level of the temperature by a thermometer and a level of humidity by a hygrometer. To develop a method one realized objectify to determine the general pace of a worker the following steps has been performed:

- Determination of the immediate speed of the worker according to the following equation:

$$
I P=\frac{S T \times 100}{A T}
$$

where IP is the instantaneous pace, $S T$ - the standard time and $A T$ - the average time of task.

- The reference time is determined by the sewing time measuring method [9]. The average time of the operation is determined by the average of 20 statements for each post.

- Determination of percentage of defect; which is calculated by comparing the number of defects due to the workforce with regard to the number of pieces worked during a day.

- Determination of ambient coefficient that depends on the temperature and humidity level according to the BTE [13].

- Determination of the sound coefficient according to the standard NFEN ISO 9612.

- Determination of the lighting coefficient according to the NBNEN standard 12464-1.

A new method was developed to determine the general pace of a worker according to the following parameters; instantaneous pace, ambient coefficient, sound coefficient, lighting coefficient and percentage of defects.

\section{RESULTS}

The analysis of noise level was done on a group of 47 workers. The made tasks are repetitive and continuous during all day with a break of 30 minutes. The sources of noise are due to machines and to ventilators used for the ironing. The noise level was measured for each post when the machine is out of work that is the worker executes a manual task and when the machine is working. The results are summarized in the table 1.

According to the table 1 , the percentage of manual task and technological time varies from a task to another one according to the complexity and to the operating procedure of every task. The noise level depends on the speed of the machine, on sound noise of the machine and on level of the noise accumulated by the nearby machines. The noise level varies between $73 \mathrm{dBA}$ and $90 \mathrm{dBA}$ when the machine is operating. For the posts of ironing, the noise level depends on the use or not of the ventilator. The average exposure level for the "pressing button" and "pressing buttonhole" positions is equal to 85 dBA, which means that there is a risk. For the cleaning station, the average exposure level is 76.5 $\mathrm{dBA}$, so no risk for this post. For other posts; Simple sewing machine, zigzag, ironing and Welt pocket, the 


\begin{tabular}{|l|c|c|c|c|c|c|c|c|c|}
\hline \multicolumn{8}{|c|}{ RESULT OF THE NOISE LEVEL MEASUREMENT FOR DIFFERENT POSTS } \\
\hline $\begin{array}{c}\text { Machine/ } \\
\text { task }\end{array}$ & $\begin{array}{c}\text { Number } \\
\text { of posts }\end{array}$ & Time (s) & $\begin{array}{c}\text { \% of } \\
\text { manual } \\
\text { task }\end{array}$ & $\begin{array}{c}\text { \% of tech- } \\
\text { nological } \\
\text { time }\end{array}$ & $\begin{array}{c}\text { Level } \\
\text { noise } \\
\text { (dBA) } \\
\text { (manual } \\
\text { task) }\end{array}$ & $\begin{array}{c}\text { Level } \\
\text { noise } \\
\text { (dBA) } \\
\text { (machine } \\
\text { on works) }\end{array}$ & $\begin{array}{c}\text { LAeq, Te } \\
\text { (average) }\end{array}$ & $\begin{array}{c}\text { LEx,8H } \\
\text { (average) }\end{array}$ & $\begin{array}{c}\text { \% } \\
\text { compared } \\
\text { to 85 dBA }\end{array}$ \\
\hline $\begin{array}{l}\text { Simple sewing } \\
\text { machine }\end{array}$ & 31 & 2724.38 & 48.57 & 51.43 & 76.7 & 89.5 & 86.8 & 87.3 & $3 \%$ \\
\hline $\begin{array}{l}\text { Zigzag stitch } \\
\text { machine }\end{array}$ & 1 & 80 & 27.5 & 72.5 & 75 & 89 & 87.8 & 88.2 & $4 \%$ \\
\hline Ironing & 9 & 648.125 & 42.23 & 57.77 & 84.4 & 88.2 & 87.8 & 88.3 & $4 \%$ \\
\hline $\begin{array}{l}\text { Pressing } \\
\text { buttonhole }\end{array}$ & 2 & 79.125 & 63.65 & 36.35 & 76 & 90 & 84.6 & 85.1 & $0 \%$ \\
\hline $\begin{array}{l}\text { Pressing } \\
\text { button }\end{array}$ & 1 & 34 & 76.5 & 23.5 & 79 & 90 & 84.7 & 85.2 & $0 \%$ \\
\hline Cleaning & 2 & 228 & 100 & 0 & 76 & 76 & 76 & 76.5 & $-10 \%$ \\
\hline Welt pocket & 1 & 40 & 62.5 & 37.5 & 75 & 90 & 86 & 86.5 & $2 \%$ \\
\hline
\end{tabular}

difference compared to the limit given by the standard varies between $2 \%$ and $4 \%$. So, the risk is very high which leads to a danger on the eye and therefore a risk of deafness [14].

According to the standard NBN EN 12464-1, the maximum lighting for a stitching post is equal to 750 Ix, for ironing must be equal to 300 and for control the maximum illumination is equal to $1000 \mathrm{~lx}$. According to the French association of lighting, the lighting level varies between $250 \mathrm{~lx}$ and $850 \mathrm{~lx}$ [15]. Therefore, the lighting does not conform to the standard and the level of illumination is higher than, what is required by the standard which causes negative effects on the health of the worker such as the dazzle of the eyes, headaches and fatigues which decreases the concentration and increases the risk of work accidents and therefore lowers productivity. According to the figure 1, the ratio (Lz/Ls) varies between 0.69 and 4.11 and the ratio (Ls/Lb) varies between 2.18 and 17.12 which does not meet the standard which requires that the ratio between the level of the lighting of the working zone and the surrounding zone (Lz/Ls) shall be 1.5 and the ratio of the lighting level of the surrounding zone to the bottom zone shall be 3 . The analysis of the atmosphere showed that the temperature level varies between $26^{\circ} \mathrm{C}$ for the stitching posts and $28^{\circ} \mathrm{C}$ for the ironing posts. This means that the ambient coefficient varies between 1.1 and 1.25 [13]. To determine the general pace GP of each worker, the following model is proposed:

$$
G P=\frac{I P \times(1-\% D)}{C_{A} \times C_{S} \times C_{L}}
$$

The instantaneous pace must be corrected by the sound coefficient $C_{S}$ according to the following formula:

$$
C_{S}=\frac{L_{E X, 8 H}-85 \mathrm{~dB}}{85 \mathrm{~dB}}
$$

According to the results of the noise analysis, the exposure level varies between $10 \%$ and $6.5 \%$ com-

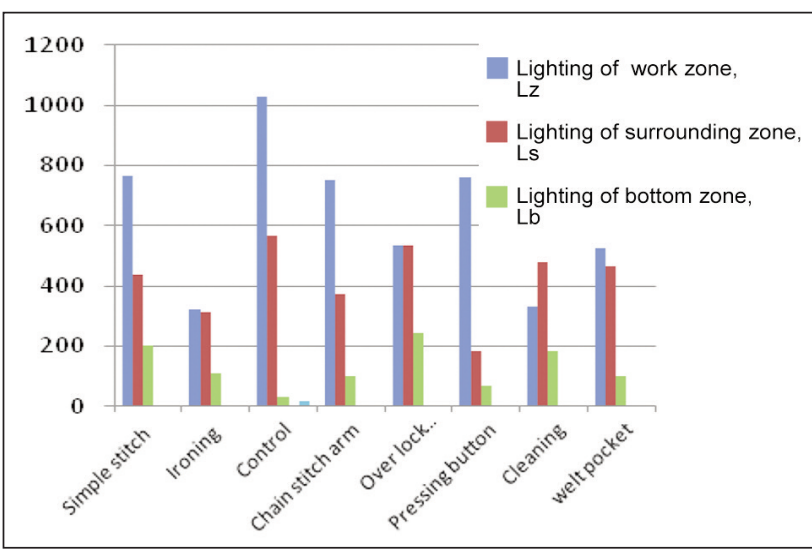

Fig. 1. Variation of the lighting level for different workplaces

pared to $85 \mathrm{~dB}$ so a sound coefficient between 09 and 1.065 .

The best lighting according to the French association, the lighting level varies between $250 \mathrm{~lx}$ and 850 Ix [15]. For stitching stations and according to the standard NBN EN 12464-1 the maximum acceptable lighting is $750 \mathrm{~lx}$. For the ironing post the maximum lighting is $300 \mathrm{~lx}$ and for the control post is $1000 \mathrm{~lx}$. To calculate the lighting coefficient $C_{L}$ the following formulas are used:

For the sewing posts:

$$
C_{L}=\frac{L_{\text {Max }}-700 \mathrm{~lx}}{700 \mathrm{Ix}}+1
$$

For the ironing posts:

$$
C_{L}=\frac{L_{\text {Max }}-300 \mathrm{Ix}}{300 \mathrm{Ix}}+1
$$

For the control posts:

$$
C_{L}=\frac{L_{M a x}-1000 \mathrm{~lx}}{1000 \mathrm{~lx}}+1
$$

where $L_{\text {Max }}$ is the lighting level for working zone. 
noise are manifest at the physiological and behavioral level, which increases the risk of

PERCENTAGE OF VARIATION OF THE GENERAL PACE COMPARED TO THE INSTANTANEOUS PACE

\begin{tabular}{|c|c|c|c|c|}
\hline Variation & Minimal & Maximal & Average & $\begin{array}{c}\% \text { compared } \\
\text { to IP }\end{array}$ \\
\hline $\begin{array}{l}\text { Instantaneous } \\
\text { Pace IP }\end{array}$ & 69 & 113 & 98 & \multirow{3}{*}{$0.66 \%$} \\
\hline$\%$ of defects & $0 \%$ & $5 \%$ & $1 \%$ & \\
\hline Pace 1 & 68 & 112 & 97 & \\
\hline $\begin{array}{l}\text { Ambient } \\
\text { coefficient } C_{A}\end{array}$ & 1.1 & 1.25 & 1.13 & \multirow{3}{*}{$11.92 \%$} \\
\hline Pace 2 & 62 & 99 & 86 & \\
\hline Lex,8H & 76.5 & 89.5 & 87 & \\
\hline $\begin{array}{l}\text { Sound } \\
\text { coefficient } C_{S}\end{array}$ & 0.9 & 1.06 & 1.02 & \multirow[t]{2}{*}{$13.79 \%$} \\
\hline Pace 3 & 60 & 100 & 85 & \\
\hline Lmax & 240 & 900 & 649 & \multirow{3}{*}{$20.66 \%$} \\
\hline $\begin{array}{l}\text { Lighting } \\
\text { coefficient } C_{L}\end{array}$ & 1 & 1.33 & 1.09 & \\
\hline $\begin{array}{l}\text { General Pace } \\
\text { GP }\end{array}$ & 60 & 93 & 78 & \\
\hline
\end{tabular}

an accident at work since it disturbs verbal communication and distracts attention [21]. According to the regulations of the National Institute of Health and Safety (NIOSH) the daily exposure level for a day of 8 working hours should not exceed then $85 \mathrm{~dB}$ [16] otherwise the risk becomes higher. In addition, beyond then $85 \mathrm{~dB}$ for an extended period, the risk of hearing loss increases exponentially [22]. To reduce the risk of noise, it is essential to apply a preventive solution to the exposure of noise: acoustic treatment of work premises, partitioning and enclosure of machines (enclosure built around the machine to reduce the noise level), soundproofing of ceilings and walls, these are the most effective preventive actions [11].

Noisy machines will be equipped with a noise-canceling system is a method to prevent the spread of noise by the ground. Better machine maintenance and regular lubrication are ways to reduce the level of

The case study showed that the lighting level for the stitching posts varies between $240 \mathrm{Ix}$ and $900 \mathrm{Ix}$, namely the lighting coefficient varies between 1 and 1.33 depending on the type of workplace.

The percentage of defect is also an element that influences the pace $P$ of the worker. This pace must be corrected for this default percentage as follows:

$$
P=I P \times(1-\% D)
$$

The case study in the same group of work showed in table 2.

\section{DISCUSSIONS}

The best organization of workplace reduces the risk factors for diseases of MSDs in the hands, wrists, elbows, shoulders, neck and at the level of lower back, feet and legs [1-3]. But this organization does not reduce other risk factors because the noise exposure at a high noise level exceeds then $85 \mathrm{~dB}$ for 8 hours per day of work [16]. Noise effects are in the order of three groups: acoustic trauma, temporary hearing loss and permanent hearing loss [17]. Noise promotes health problems such as hearing fatigue, deafness which is irreversible fatigue because of the sound exposure for a slow period. The noise also causes cardiovascular disorders which are especially hypertension and therefore a loss of concentration and increase in absenteeism [18]. Noise also promotes sleep disorders; it is also an unpredictable and uncomfortable work stress factor. It can also cause fatigue, irritability, headaches and decreased hearing $[19,20]$. Noise causes discomfort or stress vector disorders and pathologies that affect not only the health of the worker but also productivity by lowering the concentration [18]. The non-traumatic effects of noise [11]. Personal protections such as ear muffs and ear plugs are short-term solutions to the problem of noise [19]. Workers must be trained in noise and its effects on human health [14].

The ergonomics of lighting makes possibilities to avoid the under lighting and the over lighting of workplace. The lighting of a work zone must be neither too much lighting to avoid glare of the eyes, nor with low lighting to avoid the boring and not stimulating work. Indeed, the best lighting avoids eye fatigue and also allows having a visible task and avoiding the risk of errors and improving productivity in the best visual comfort. Bad lighting can increase the risk of error, increases stress, and produce visual discomfort therefore risk of dazzling eyes [23]. Fluctuating lights can cause visual disturbances and increases the risk of work-related accidents [24]. Symptoms caused by a bad lighting are: rapid fatigue, headaches, visual fatigue, decreased ability to concentrate and stress, degeneration of sharpness of vision [6]. To optimize the lighting level, it is necessary to measure and control the lighting and distribute the lighting system evenly for all stitching posts.

The level of humidity and temperature has an effect on the work rhythm and the health of the worker. Studies have been done to give the optimal environment zones for the comfort of the human being, with a temperature of $22^{\circ} \mathrm{C}$ and the optimum humidity zone varies between $40 \%$ and $65 \%$ [25]. According to this study, the average temperature level varies between $28^{\circ} \mathrm{C}$ for the ironing stations and $26^{\circ} \mathrm{C}$ for the other stations and the average humidity level is $50 \%$, so the ambient coefficient varies between 1.1 and 1.25. Pace judgment is an estimate by which the speed of work of a performer is judged in relation to the base speed called the reference pace (100) [26]. 
Indeed, the pace depends on several parameters such as the qualification of the worker, the quality of his work obtained, his physical effort, his physical and mental state still the pace depends on the physical environment of the work (noise, light, temperature ...) [26].

The majority of innovations and research in the apparel industries have been made on the improvement of management processes [27], as well as on the comfort of the garment and the creation of products meeting specific requirements and aesthetics. This article is directed towards organizational research by proposing an objective method of the pace of a worker according to ambient parameters and the percentage of defects.

\section{CONCLUSIONS}

The clothing industry is the most important source of occupational diseases with regard to TMS disorders, deafness diseases and eye diseases. This study was done in order to analyze the workplace for a stitching post to develop a method that allows determining the general pace of a worker according to percentage of quality and the ambient parameters in terms of regarding the sound level, the lighting level and the temperature and humidity level.

The lighting level varies between $240 \mathrm{Ix}$ and 1100 depending on the type of workplace that is to say a coefficient that varies between 1 to 1.33; the sound level 75-90.5 dB and the sound coefficient 0.9-1.06 and the ambient coefficient 1.1 to 1.25 depending on the type of workplace. The percentage of quality varies between 0 and $5 \%$. According to these parameters, the average pace of the group decreased from 98 to 78 .

\section{REFERENCES}

[1] David, G.C., Ergonomic methods for assessing exposure to risk factors for work-related musculokeletal disorders, In: Occupational Medicine, 2005, 55, 3, 190-199

[2] Aptel, M., Aublet-Cuvelier, A., Cnockert, J-C., Les troubles musculosquelettiques du membre supérieur liés au travail, In : Revue du Rhumatisme, 2002, 69, 12, 1181-1190

[3] Lakhal, A., Sejri, N., Chaabouni, Y., Jaafar, F., Cheikhrouhou, M., Ergonomic Analysis In A Company Of Clothing And Evaluation Of An Ergonomic Index Related To Msds, In: International Journal of Research and Reviews in Applied Sciences, 2017, 31, 2, 46-53

[4] Eleftheriou, P.C., Industrial noise and its effects on human hearing, In: Applied Acoustics, 2002, 63, 1, 35-42

[5] Forouhid, A.E., Khaki, A.M., Shirazian, S.G., Mathematical Analysis of Noise in multi-plant Industries of tyre and the need to reduce Noise, In: Journal of Progressive Research in Mathematics, 2015, 3, 1, 140-146

[6] Woodside, G., Kocurek, K., Environmental safety and health engineering, In: New York: John Wiley \& Sons Inc, 1997

[7] NF EN ISO 9612, Acoustique - Détermination de l'exposition au bruit en milieu de travail - Méthode d'expertise, 2009

[8] NBN EN 12464-1, lumière et éclairage des lieux de travail - partie 1: Lieux de travail intérieur, 2011

[9] Lakhal, A., Sejri, N., Chaabouni, Y., Jaafar, F., Cheikhrouhou, M., Analysis of the Sewing Time in a Clothing Industry, In: Transylvanian Review, 2017, 21, 16, 3602-3610

[10] Bruel, P.V., Do we measure damaging noise correctly, In: Noise Control Engineering, 1977, 8, 52-60

[11] Evaluation des risques professionnels, In: Institut National de Recherche et de Sécurité INRS, 5e Edition, 2013

[12] Reinhold, K., Tint, P., Lighting of workplaces and health risk, In: Elektronika ir elektrotechnika, 2009, 90, 2, 11-14

[13] Barbier, P., Le Bureau des temps élémentaires, précurseur de l'étude du travail, 127e Congrès National des Sociétés Historiques et Scientifiques, 2006, 237-249

[14] Atmaca, E., Peker, I., Altin, A., Industriel Noise and Its Effects on Humans, In: Polish journal of environmental studies, 2005, 14, 6, 721-726

[15] Kitronza, P.L., Philippe, M., Environmental factors associated with textile industry in Democratic Republic of Congo: state of play, In: the Pan African Medical Journal, 2016, 25, 1-11

[16] USEPA (United States Environmental Protection Agency), Information on levels of environmental noise requisite to protect public health and welfare with adequate margin of safety, EPA/ONAC REP, 1974

[17] Melamed, S., Fried, Y., Froom, P, The interactive effect of chronic exposure to noise and job complexity on changes in blood pressure and job satisfaction: A longitudinal study of industrial employees, In: Journal of occupational health psychology, 2001, 6, 3, 182-195

[18] Ibrahim, A., Aremu, A., Ajao, K., Ojelabi, A., Evaluation of noise pollution and effects on workers during wheat processing, In: Journal of application science environmental management, 2014, 18, 4, 599-601

[19] Dalapicula, D.B., Gama, S., Risk analysis of noise in industry makes clothes, In: Revista CEFAC, 2014, 16, 1, 39-48

[20] Cheung, C.K., Organizational influence on working people's occupational noise protection in HongKong, In: Journal of safety Research, 2004, 35, 4, 465-475

[21] Jayawardana, T.S.S., Perera, M.Y.A., Wijesena, G.H.D., Analysis and control of noise in a textile factory, In: International Journal of Scientific and Research Publications, 2014, 4, 12, 1-7

[22] Charles, A.B., Geoffrey, K.A., Industrial noise pollution and its effects on the hearing capabilities of workers: a study from saw mills, printing presses and corn mills, In: Journal African journal Health Science, 2004, 11, 1, 55-60

[23] Bridger, R.S., Introduction to ergonomics, 2rd ed, In London and New York, Taylor \& Francis, 2003 
[24] Wilkins., A.J., Nimmo-Smith, I., Slater, A.I., Bedocs, L., Fluorescent lighting, headaches and eyestrain, In: Lighting research and technology, 1989, 21, 1, 11-18

[25] Indicateurs et plages de confort thermique, Architecture et Climat, Département de l'Énergie et du bâtiment durable, In: Université catholique de Louvain, Belgique, 2013

[26] Lauriol, A., Précis d'organisation du travail dans les industries de l'habillement, Edition de l'usine nouvelle, Paris, 1979

[27] Olivia, D.N., Geanina, S.B., Anca, A.P., Criteria for process improvement in the textile and clothing sector, In: Industria Textila, 2017, 68, 3, 238-242, https://doi.org/10.35530/IT.068.03.1238

\section{Authors:}

AMIRA LAKHAL, NEJIB SEJRI, FADHEL JAAFAR, YASSINE CHAABOUNI, MORCHED CHEIKHROUHOU

University of Monastir, Textile Engineering Laboratory of ISET Ksar Hellel, 5070, Monastir, Tunisia

\section{Corresponding author:}

AMIRA LAKHAL

e-mail: a_mira1987@live.fr 